\title{
PERSEPSI DAN MINAT MAHASISWA PROGRAM STUDI AGRIBISNIS UNIVERSITAS GALUH CIAMIS UNTUK BERKARIR di BIDANG PERTANIAN (Suatu Kasus di Program Studi Agribisnis Fakultas Pertanian Universitas Galuh Ciamis)
}

\author{
PERCEPTION AND INTEREST OF GALUH CIAMIS UNIVERSITY AGRIBUSINESS \\ STUDY PROGRAM STUDENTS FOR A CAREER IN AGRICULTURE \\ (a case in the Galuh Ciamis University Faculty of Agriculture \\ Agribusiness Study Program)
}

\author{
OGI SUPRAYOGI ${ }^{1 *}$,TRISNA INSAN NOOR ${ }^{2}$, MUHAMAD NURDIN YUSUF ${ }^{1}$ \\ ${ }^{1}$ Fakultas Pertanian Universitas Galuh \\ ${ }^{2}$ Fakultas Pertanian Universitas Padjajaran \\ *E-mail : ogisuprayogi8@gmail.com
}

\begin{abstract}
ABSTRAK
Mahasiswa agribsisnis sebagai mahasiswa terdidik di bidang pertanian diharapkan mempunyai pandangan dan persepsi yang baik terhadap sektor pertanian dan diharapkan mampu memberikan kontribusi besar dalam pembangunan pertanian. Penelitian ini bertujuan untuk mengetahui : 1) persepsi mahasiswa Program Studi Agribisnis Fakultas Pertanian Universitas Galuh Ciamis untuk berkarir di bidang pertanian 2) Minat mahasiswa Program Studi Agribisnis Fakultas Pertanian Universitas Galuh Ciamis untuk berkarir di bidang pertanian 3) Hubungan parsial persepsi dengan minat mahasiswa Program Studi Agribisnis Fakultas Pertanian Universitas Galuh Ciamis untuk berkarir di bidang pertanian. Pengambilan data menggunakan metode simple random sampling dengan responden mahasiswa angkatan 2015 sampai 2018 sebanyak 84 orang. Hasil penelitian menunjukkan sebanyak $62 \%$, persepsi mahasiswa berada pada kategori tinggi, dan 56\% minat mahasiswa berada pada kategori tinggi. Secara parsial terdapat hubungan positif yang nyata antara faktor internal persepsi dan faktor eksternal persepsi dengan minat untuk berkarir di bidang pertanian. Hubungan positif tersebut menyatakan bahwa semakin tinggi persepsi mahasiswa maka akan semakin tinggi pula minatnya bekerja di sektor pertanian.
\end{abstract}

Kata kunci: mahasiswa, Agribisnis, karir di bidang pertanian.

\section{ABSTRACT}

Agribusiness students as educated students in agriculture are expected to have good views and perceptions of the agricultural sector and are expected to be able to provide a major contribution to agricultural development. This study aims to determine: 1) perceptions of students of the Agribusiness Study Program of the Faculty of Agriculture of Galuh Ciamis University for a career in agriculture 2) The interest of students of Galuh Ciamis University's Agribusiness Study Program for a career in agriculture 3) The relationship of partial perceptions of student interest in the Faculty of Agribusiness Study Program Galuh Ciamis University Agriculture for a career in agriculture. Data retrieval using a questionnaire with student respondents from 2015 to 2018 as many as 84 people were taken proportionally using the Slovin formula. The results showed 62\%. student perceptions are in the high category, and $56 \%$ of student interests are in the high category. Partially there is a real positive relationship between internal factors of perception and perceptual external factors with an interest in a career in agriculture, the poditive relationship states that the higher the perception of students, the higher their interest will be.

Keywords: students, agribusines, careers in agricultur. 


\section{PENDAHULUAN}

Indonesia merupakan negara yang kaya akan sumber daya alam serta merupakan negara kepulauan yang terkenal dengan sebutan negara agraris karena sebagain besar penduduknya bermatapencaharian sebagai petani. Pertanian merupakan sektor primer dalam perekonomian Indonesia, artinya pertanian merupakan sektor utama yang menyumbang hampir setengah dari perekonomian (Sjamsir, 2017).

Pentingnya sektor pertanian untuk masa kini dan masa depan menjadi perhatian berbagai pihak. Menurut Ritonga (2015) untuk menunjang pembangunan pertanian yang berkelanjutan dibutuhkan tiga faktor yaitu sumber daya alam, sumber daya manusia, dan teknologi tepat guna. Salah satu sumber daya yang ideal untuk keberlangsungan pembangunan pertanian masa depan adalah sumberdaya manusia terdidik.

Indonesia dengan sumber daya alam yang kaya dan beragam berpotensi untuk berkembangnya sektor pertanian, namun saat ini sumber daya manusia di Bidang pertanian sebagian besar berusia tua. Hal tersebut disebabkan generasi muda kurang tertarik bekerja di Bidang pertanian. Sejalan dengan yang dikemukakan Werembinan, (2018) yang menyebutkan bahwa generasi muda memiliki persepsi berbeda-beda terhadap pekerjaan di Bidang pertanian.

BPS dalam Sensus Pertanian tahun 2013 menunjukkan bahwa 60.8 persen dari total petani indonesia berada pada usia di atas 45 tahun.

\section{Tabel 1. Jumlah Petani Indonesia}

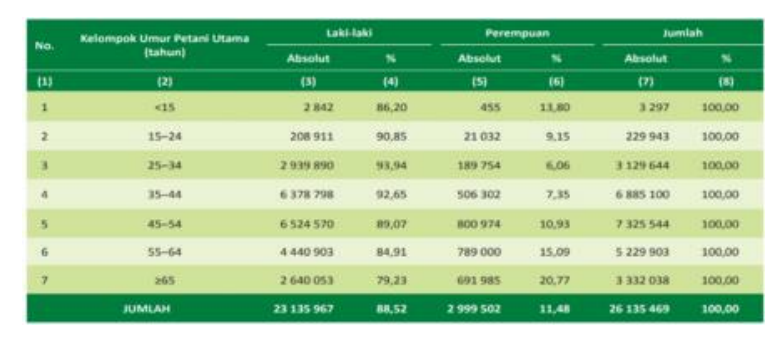

Sunber : BPS (2013)

Tabel 1. Menunjukan bahwa petani di Indonesia lebih didominasi oleh petani yang berusia tua (> 45). Hal tersebut sejalan dengan yang dikemukakan oleh Pribadi (2017) yang menyatakan bahwa, dalam satu dekade terakhir terdapat penurunan jumlah rumah tangga petani dari 31,2 juta petani menjadi 26.1 juta. Demikian pula jumlah petani dengan usia produktif terus menurun dari 53 persen menjadi 43,3 persen, sedangkan petani yang berusia lebih dari 55 tahun cenderung mengalami peningkatan dari 23,4 persen menjadi 31,2 persen. Kondisi ini terjadi akibat generasi muda yang berusia produktif lebih tertarik pada bidang non pertanian dibanding bekerja di sektor pertanian. 
Menurut Werembinan, (2018), kurang tertariknya generasi muda terhadap sektor pertanian disebabkan oleh persepsi mereka terhadap bidang pertanian yang kurang menjanjikan, sehingga minat untuk mengembangkan potensi pertanian untuk masa depan tidak tertanam dalam pola pikir generasi muda. Pekerjaan dilahan pertanian sudah mulai berkurang sejak kurangnya minat generasi muda untuk bergabung atau bekerja sebagai petani

Mahasiswa agribisnis sebagai generasi muda terdidik di Bidang pertanian diharapkan mempunyai pandangan dan persepsi yang baik terhadap sektor pertanian, sehingga mampu mengambangkan pertanian dengan ilmu yang dimilikinya supaya dapat memanfaatkan kekayaan alam Indonesia di Bidang pertanian secara maksimal. Namun demikian, tidak semua mahasiswa agribisnis mempunyai keinginan untuk mengembangkan dan memanfaatkan sektor pertanian secara intensif.

Program Studi Agribisnis Fakultas Pertanian Universitas Galuh Ciamis yang setiap tahunnya meluluskan sumber daya manusia terdidik di Bidang pertanian diharapkan mampu memberikan kontribusi besar dalam pengembangan pertanian. Namun demikian tidak semua mahasiswa Program Studi Agribinis
Universitas Galuh Ciamis mempunyai persepsi yang sama untuk berkarir.

Hipotesis yang di ajukan dalam penelitian ini adalah sebagai berikut :

"Terdapat hubungan secara parsial antara faktor persepsi mahasiawa Program Studi Agribisnis Fakultas Pertanian Universitas Galuh Ciamis dan minat untuk berkarir di Bidang pertanian"

\section{METODE PENELITIAN}

\section{Tempat dan Waktu Penelitian}

Pemilihan lokasi dilakukan pada Program studi Agribisnis Fakultas Pertanian Universitas Galuh Ciamis secara Purposive dengan pertimbangan bahwa Program Studi Agribisnis Fakultas Pertanian Universitas Galuh Ciamis merupakan Program Sutdi Agribisnis terbesar di Priangan Timur. Pengumpulan data dilaksanakan pada bulan April - Juni 2019.

Metode penelitian yang digunakan adalah metode Deskriptif Kuantitatf Metode penelitian yang digunakan adalah metode Deskriptif Kuantitatf. Menurut Yusuf (2017), merupakan usaha sadar dan sistematis untuk memberikan jawaban terhadap suatu masalah dan mendapatkan informasi lebih mendalam dan luas terhadap suatu penomena dengan 
menggunakan tahap-tahap pendekatan penelitian kuantitatif.

Jenis penelitian yang digunakan adalah metode survei dengan mengambil kasus pada Program Studi Agribisnis Fakultas Pertanian Universitas Galuh Ciamis. Menurut Nazir (2011) metode survei adalah penyelidikan yang diadakan untuk memperoleh fakta dari gejala yang ada dan mencari keterangan secara faktual, baik tentang institusi sosial, ekonomi, atau politik dari suatu kelompok ataupun suatu dareah. Jumlah responden penelitian yang digunakan berdasarkan Rumus Slovin dengan standar eror $10 \%$, dari populasi mahasiswa aktif berjumah 508 orang, di dapat sampel sebanyak 83,55 digenapkan menjadi 84 orang.

Sumber data yang di kumpulkan dalam penelitian ini meliputi data primer dan data sekunder. Data primer diperoleh dari kuesioner yang berkaitan dengan informasi yang ingin diperoleh dari penelitian ini, Data sekunder diperoleh dari instansi dan departemen yang terkait dengan penelitian, serta melalui penelusuran literatur.

\section{Oprasional Variabel}

Variabel dalam penelitian ini dioperasionalisasikan sebagai berikut :
1. Persepsi adalah cara menginterpretasikan suatu objek mahasiswa Program Studi Agribisnis Fakultas Pertanian Universitas Galuh Ciamis, yang terdiri atas faktor internal dan faktor eksternal. Dengan indikator di atas didefinisikan sebagai berikut :

a. Faktor internal adalah faktor persepsi dari dalam diri mahasiswa Program Studi Agribisnis Fakultas Pertanian Universitas Galuh Ciamis untuk melakukan kegiatan usaha di Bidang pertanian.

b. Faktor eksternal adalah faktor persepsi dari luar diri mahasiswa Program Studi Agribisnis Fakultas Pertanian Universitas Galuh Ciamis untuk melakukan kegiatan usaha di Bidang pertanian.

2. Minat adalah rasa lebih suka dan rasa ketertarikan mahasiswa Program Studi Agribisnis Fakultas Pertanian Universitas Galuh Ciamis untuk berkarir di Bidang pertanian, dengan indikator sebagai berikut :

a. Ketertarikan adalah ketertarikan mahasiswa Program Studi Agribisnis Fakultas Pertanian Universitas Galuh Ciamis dalam melakukan kegiatan usaha pertanian. 
b. Keterlibatan adalah keterlibatan mahasiswa Program Studi Agribisnis Fakultas Pertanian Universitas Galuh Ciamis dalam melakukan kegiatan usaha pertanian.

c. Perhatian adalah perhatian mahasiswa Program Studi Agribisnis Fakultas Pertanian Universitas Galuh Ciamis dalam melakukan kegiatan usaha pertanian.

\section{Rancangan Analisis Data dan Uji Hipotesis}

a. Rancangan Analisis Data

Untuk mengetahui faktor persepsi dengan minat mahasiswa Program Studi Agribisnis Fakultas Pertanian Universitas Galuh Ciamis dibagi ke dalam 5 kategori yaitu sangat tinggi, tinggi, sedang, rendah, dan sangat rendah, serta dilakukan analisis secara deskriptif. Sedangkan untuk menentukan interval masing-masing kategori dilakukan perhitungan menurut Sudjana (2005) sebagai berikut :

Panjang Kelas Interval $=\frac{\text { Rentang }}{\text { Banyak Kelas }}$ Keterangan :

Rentang $=$ Nilai maksimal - Nilai Minimal

Banyak Kelas $=$ Jumlah Kategori
Nilai maksimal merupakan nilai tertinggi dari masing-masing variabel dan indikatornya, sedangkan nilai minimal merupakan nilai terendah dari masingmasing variabel dan indikatornya yang didapat dari jawaban pertanyaanpertanyaan yang diajukan.

\section{b. Rancangan Uji Hipotesis}

Uji validitas digunakan untuk mengetahui penafsiran responden terhadap setiap butir pernyataan yang terdapat dalam instrumen penelitian, apakah penafsiran setiap responden sama atau beda sama sekali. Apabila penafsiran tersebut sama maka instrumen penelitian tersebut dapat dikatakan valid, dan apabila tidak sama maka instrumen tersebut dikatakan tidak valid, sehingga perlu untuk diganti. Variabel-variabel dikatakan valid jika mempunyai koefisien korelasi (r hitung) $\geq$ (Sugiyono, 2012).

Variabel dapat dikatakan reliabel apabila Koefisien Alpha Cronbach > 0,60, yang artinya tingkat reliabilitas sebesar 0,60 adalah indikasi reliabelnya sebuah konstruk. Untuk menguji hipotesis secara parsial digunakan Uji Korelasi Rank Spearman (Sugiyono, 2012) sebagai berikut :

$r s=1-\frac{6 \sum_{\mathrm{i}=1}^{\mathrm{N}} \mathrm{d}_{\mathrm{i}}^{2}}{\mathrm{~N}^{3}-\mathrm{N}}$ 
Keterangan :

rs $\quad=$ Korelasi Rank Spearman

$d_{i}^{2}=$ Perbedaan jumlah rank $\mathrm{X}$

(Faktor persepsi) dan rank Y (Minat)

$\mathrm{N}=$ Jumlah Responden

Untuk pengujiannya digunakan uji t

(Sugiyono, 2012) dengan rumus sebagai berikut:

$t=r_{S} \sqrt{\frac{N-2}{1-\left(r_{S}\right)^{2}}}$

Keterangan :

$t=\mathrm{t}$ hitung

$\mathrm{N}=$ Jumlah data observasi

$r s=$ Korelasi Rank Spearman

Taraf kepercayaan yang digunakan dalam penelitian ini adalah $95 \%$.

Untuk mengetahui tingkat signifikansinya, maka dilakukan pengujian sesuai dengan pendapat Santoso (2012) dengan perhitungan untuk sampel besar (n lebih dari 10). Pengujian hipotesis dilakukan dengan kriteria sebagai berikut :

$\mathrm{t}$ hitung $\leq \mathrm{t} 0,05=$ sangat nyata (higly significant) $\mathrm{HO}$ di tolak

$\mathrm{t}$ hitung $\geq \mathrm{t} 0,05=$ tidak nyata (non significant) H0 di terima

Hipotesis

H0 : $\rho=0$ "Terdapat hubungan yang tidak nyata antara faktor persepsi mahasiswa Program Studi Agribisnis Fakultas
Pertanian Universitas Galuh Ciamis terhadap minat untuk berkiprah di Bidang pertanian ".

$\mathrm{H} 1: \rho \neq 0$ "Terdapat hubungan yang nyata antara faktor persepsi mahasiswa Program Studi Agribisnis Fakultas Pertanian Universitas Galuh Ciamis terhadap minat untuk berkiprah di Bidang pertanian”.

\section{HASIL DAN PEMBAHASAN}

\section{a. Identitas Responden}

Keseluruhan responden dalam penelitian ini berada pada usia antara 18 sampai 23 tahun. Menurut undang-undang Nomor. 40 tahun 2009 warga Negara Indonesia berusia 16-30 tahun yang memasuki priode penting pertumbuhan dan perkembangan disebut sebagai pemuda (BPS, 2017). Hasil penelitian menunjukkan, responden dalam penelitian ini lebih didominasi oleh perempuan. Latar belakang pendidikan responden mayoritas berasal dari SMA (Sekolah Menengah Tingkat Atas) hal tersebut terjadi karena responden yang berasal dari SMA sudah dipersiapkan untuk masuk ke perguruan tinggi.

\section{b. Prioritas Pilihan Karir Setelah Lulus Kuliah \\ Pilihan prioritas karir setelah lulus dari perguruan tinggi sangat penting bagi}


responden karena akan menentukan apakah responden akan berkarir sesuai ilmu yang dimiliki atau berkeinginan untuk berkarir dibidang keilmuan yang lain. Hasil analisis menunjukkan bahwa mayoritas responden memilih wirausaha dan sektor pemerintahan/negeri sebagai prioritas utama pemilihan pekerjaan setelah lulus dan menjadi sarjana pertanian (Gambar 1). Responden memilih sektor pemerintahan/negeri dan wirausaha sebagai prioritas pilihan karir disebabkan karena, penghasilan sebagai pegawai negeri lebih menjamin dari sisi finansial serta adanya jenjang karir yang lebih jelas. Mahasiswa memilih wirausaha sebagai prioritas utama pemilihan karir disebabkan karena tidak ingin diatur dan ingin bebas melakukan pekerjaan sesuai keinginannya.

Hasil penelitian Muwartami (2014) menyatakan bahwa sebagian besar mahasiswa IPB setelah lulus dari perguruan tinggi lebih memilih untuk berkarir di sektor pemerintahan/negeri, karena kehidupan sebagai PNS kedepannya lebih terjamin, seperti tersedianya tunjangan untuk pegawai yang telah pensiun. Selanjutnya Segal dkk (2005), mengungkapkan bahwa keberhasilan diri dan keinginan untuk merasakan kebebasan dalam pekerjaan dapat mempengaruhi keinginan berwirausaha.

Responden yang memilih sektor swasta sebagai pilihan karir beralasan bahwa mereka belum mampu menanggung resiko berwirausaha dan sulitnya masuk seleksi menjadi seorang pegawai negeri sipil.

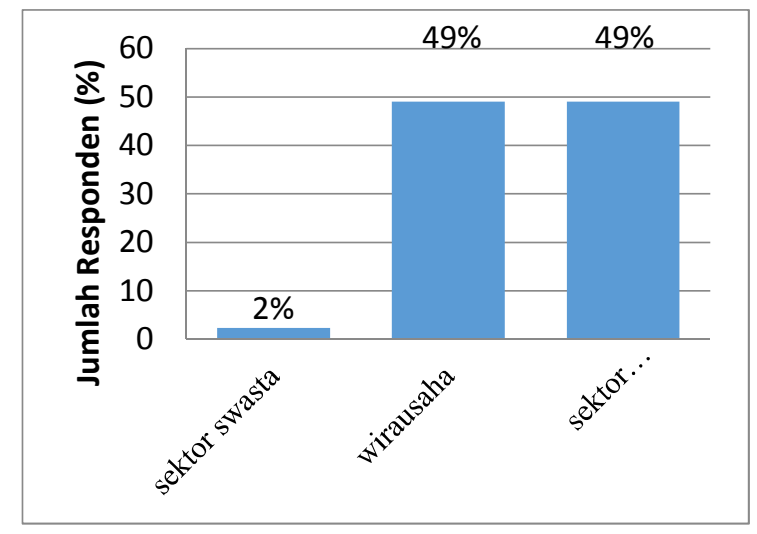

Gambar 1.

\section{Prioritas Pilihan Karir Responden Setelah Lulus Kuliah}

\section{c. Persepsi Mahasiswa}

a. Faktor Internal Persepsi Mahasiswa Rata-rata jawaban responden berada pada kategori setuju. Hal ini mengindikasikan bahwa responden menyatakan mempunyai motivasi tinggi untuk berkarir di Bidang pertanian. Irianto (2005), dan Hutapea (2016), mengungkapkan bahwa motivasi adalah sesuatu yang menggerakan atau mendorong seseorang atau kelompok orang, untuk melakukan atau tidak melakukan sesuatu. Hal yang memotivasi responden untuk berkarir di Bidang 
pertanian salah satunya adalah lingkungan keluarga, responden menyatakan mempunyai orang tua atau saudara yang telah berkarir di Bidang pertanian dan memberikan dorongan serta dukungan untuk melakukan hal yang sama. Satu dari beberapa faktor yang dapat mempengaruhi perkembangan karir individu adalah keluarga

Selain motivasi bakat merupakan salah satu faktor fsikologis yang dapat mempengaruhi faktor internal persepsi responden. Menurut Setiawan dalam Misbach (2010), bakat adalah kemampuan inherent dalam diri seseorang, dibawa sejak lahir dan terkait dengan struktur otak. Responden menyatakan bahwa mempunyai bakat untuk berkarir di Bidang pertanian, untuk itu responden memilih Program Studi Agribisnis sebagai sarana mengasah bakat di Bidang pertanian yang dimiliki.

Keadaan yang dirasakan tidak ada dalam diri seseorang didefinisikan sebagai kebutuhan (Rahman, 2010). Dilihat dari sisi kebutuhan untuk berkarir di Bidang pertanian, mayoritas responden menyatakan setuju, hal tersebut mengindikasikan bahwa berkarir di Bidang pertanian merupakan suatu kebutuhan dan perlu dilakukan, karena latar belakang responden merupakan mahasiswa yang terdidik dan akan lulus menjadi seorang sarjana pertanian. Sebagaimana yang diungkapkan Muhson (2012) dalam penelitiannya yang menyatakan bahwa terdapat relevansi mahasiswa jurusan pendidikan ekonomi dengan pekerjaan yang dijalani yaitu sebagai pendidik.

Dilihat dari sisi pengalaman, responden mengungkapkan bahwa belum mempunyai pengalaman yang cukup untuk berkarir di Bidang pertanian. Namun responden menyatakan setuju, Hal itu tidak mengurangi keinginan untuk tetap berkarir di Bidang pertanian, meskipun jika dilihat dari segi pengalaman karir responden belum perpengalman. Hal tersebut mengindikasikan bahwa responden merasa telah memiliki dasar keilmuan yang sesuai untuk bekerja di Bidang pertanian. Subrata dkk (2016), ilmu spesifik yang sesuai dengan profesi sangat diperlukan sebagai modal dasar pada saat membuat keputusan dalam menentukan pekerjaan.

dari ketiga indikator Faktor internal persepsi yang terdiri atas faktor fsikologis responden, kebutuhan dan pengalaman, semuanya berada pada kategori tinggi dengan Rata-rata skor pada kisaran $14 \leq \mathrm{Q}$ < 17 yaitu 16 (Gambar 2). 


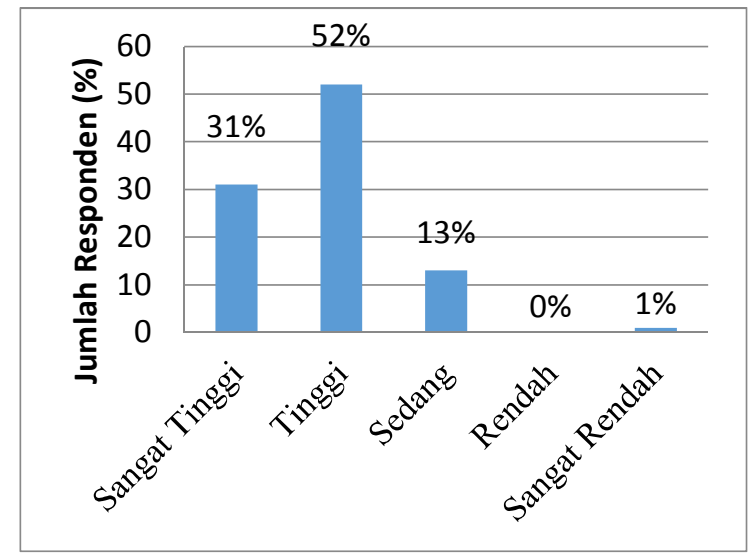

Gambar 2.

\section{Tingkat Faktor Internal Persepsi}

\section{b. Faktor Eksternal Persepsi Mahasiswa}

Latar belakang tingginya faktor eksternal persepsi responden terhadap karir di Bidang pertanian dipengaruhi oleh latar belakang keluarga. Latar belakang keluarga responden lebih didominasi oleh petani atau yang berkarir di Bidang pertanian. Hasil penelitian Purwanta (2013) menunjukkan bahwa pihak yang paling membantu dalam perencanaan karir berturut-turut dari ranking tertinggi adalah keluarga. Hasil penlitain Jusmin (2012) mengungkapkan bahwa latar belakang keluarga berpengaruh signifikan terhadap kesiapan karir berwirausaha siswa SMKN Tanah Bumbu. Responden setuju jika latar belakang keluarga sebagai seorang petani atau yang berkarir dalam bidang pertanian akan membuat responden lebih mudah untuk berkarir dibidang tersebut karena responden merasa sudah mempunyai bekal dan sedikit belajar dari keluarga.

Responden mengungkapkan sering mencari informasi karir di Bidang pertanian melalui internet dan media massa guna memperbarui informasi. Saat ditanya apakah responden pernah mendapatkan informasi pengusaha sukses di Bidang pertanian, responden menyatakan setuju. pernah mendapatkan informasi tentang pengusaha yang sukses di Bidang pertanian melalui media masa dan merasa termotivasi untuk melakukan hal yang sama. Romli (2017) media masa cukup berpengaruh terhadap apa yang dipikirkan orang. Ini berarti media massa dapat mempengaruhi khalayak tentang apa yang dianggap penting.

Responden menyatakan setuju bahwa inovasi yang berkembang saat ini di Bidang pertanian mempengaruhi keinginannya untuk berkrir dibiadang pertanian. Menurut responden, semakin berkembangnya inovasi dan teknologi dalam bidang pertanian berpangurh terhadap keinginannya untuk berkarir di Bidang pertanian, hal tersebut mengindikasikan bahwa, semakin beragamnya inovasi dan teknologi pertanian yang ditawarkan akan membuat keinginan respoden semakin tinggi untuk berkarir di Bidang pertanian. dari tiga 
indikator faktor eksternal persepsi, Ratarata skor berada pada kisaran $14 \leq \mathrm{Q}<17$ yakni 15, hal tersebut mengindikasikan bahwa faktor eksternal persepsi responden berada pada kategori yang tinggi (Gambar $3)$.

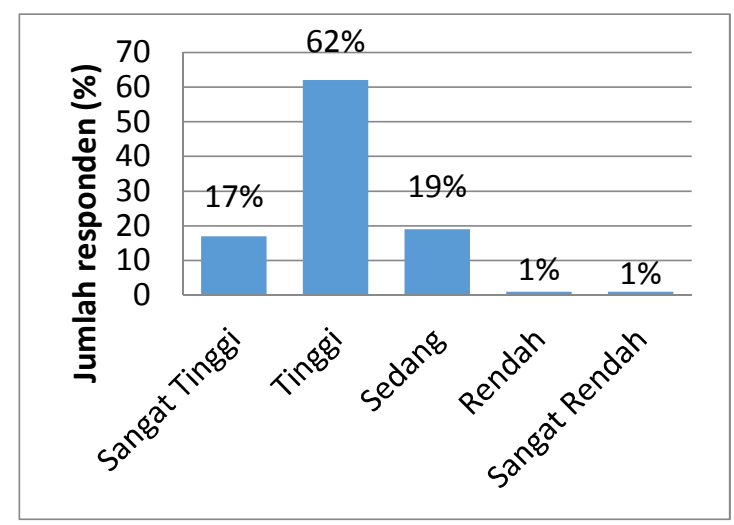

\section{Gambar 3.}

\section{Tingkat Faktor Eksternal Persepdi}

c. Tingkat Persepsi Mahasiswa

Dapat disimpulkan secara keseluruhan, tingkat persepsi mahasiswa berada pada kategori tinggi (Gambar 4), dengan Rata-rata skor $28 \leq \mathrm{Q}<34$ yaitu 31. Hal ini terjadi karena, baik dari sisi faktor internal persespi ataupun faktor eksternal persepsi mahasiswa Program Studi Agribisnis Fakultas Pertanian Universitas Galuh, semuanya berada pada kategori tinggi. Dari hasil analisis menunjukkan bahwa, motivasi, bakat, kebutuhan, pengalaman, latar belakang keluarga, informasi dan inovasi, sangat berperan dalam pembentukan persepsi mahasiswa untuk berkarir di Bidang pertanian.

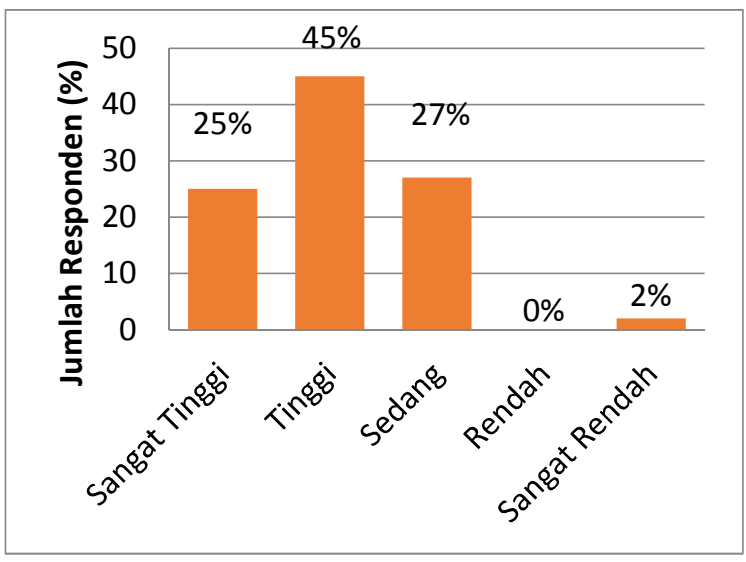

Gambar 4.

Tingkat Persepsi Responden

\section{d. Minat Mahasiswa}

a. Ketertarikan

Responden menyatakan setuju lebih senang untuk berkarir di Bidang pertanian. Hal tersebut menunjukkan bahwa, jika dibandingkan dengan pekerjaan yang lainnya, responden akan merasa senang saat melakukan pekerjaan di Bidang pertanian. Alasan responden merasa lebih tertarik dan lebih senang mencari peluang karir di Bidang pertanian karena masih banyaknya peluang dalam bidang pertanian dan kesempatan masih terbuka lebar. Data BPS (2013) menunjukkan bahwa, produk pertanian indonesia berpeluang merajai pasar global ditengah persaingan dengan negara agraris lain. Responden juga merasa semangat untuk berkarir di Bidang pertanian mengingat masih banyaknya potensi pertanian yang belum 
dimanfaatkan secara optimal oleh petani dan masih kurangnya pemanfaatan nlai tambah hasil pertanian, dari total 26,1 juta rumah tangga usaha pertanian, hanya 9 persen yang melakukan pengolahan hasil produksi sendiri. Artinya hampir semua rumah tangga petani hanya menjual langsung seluruh hasil pertaniannya (BPS, 2013).

Tingginya tingkat ketertarikan juga dipengaruhi oleh rasa bahagia responden saat melakukan kegiatan pertanian, rasa bahagia tersebut timbbul ketika responden melakukan kegiatan belajar, praktik, dan yang lainnya. Mayoritas responden menyatakan Setuju, menyukai segala jenis pekerjaan dan kegiatan di Bidang pertanian.

Berdasarkan hasil analisi dapat diketahui bahwa tingkat ketertarikan mahasiswa untuk berkarir di Bidang pertanian berada pada kategori tinggi (Gambar 5) dengan Rata-rata skor $16.8 \leq$ $\mathrm{Q}<20.4$ yaitu 18. Hal tersebut terjadi karena, responden merasa senang dan bahagia saat melakukan kegiatan pertanian atau bekerja di Bidang pertanian.

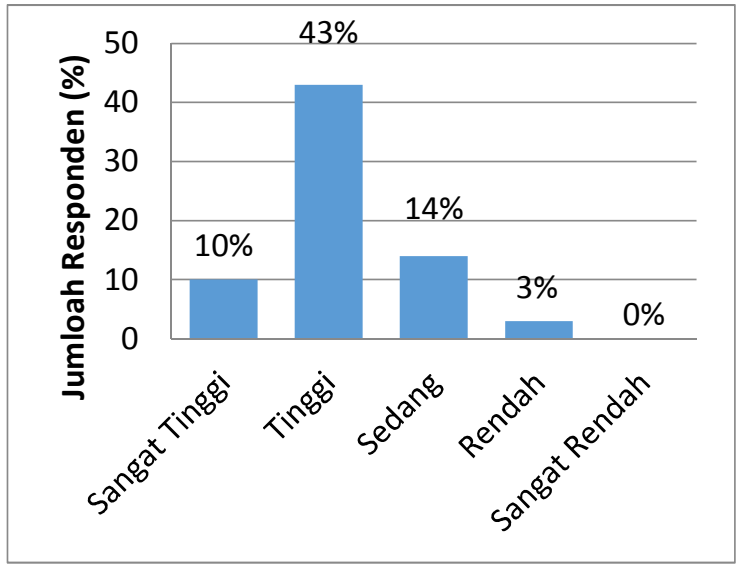

\section{Gambar 5.}

\section{Ketertarikan Mahasiswa Terhadap karir di Bidang Pertanian}

\section{b. Keterlibatan}

Sebagian besar responden menyatakan setuju, bahwa pernah ataupun telah memiliki usaha di Bidang pertanian, selain itu responden juga menyatakan setuju bahwa pernah mengolah lahan pertanian dan menjual hasilnya, Porajouw (2014) dalam penelitiannya menyatakan bahwa terdapat hubungan yang nyata antara pengalaman petani dengan minat bertani. Responden yang tidak memiliki usaha atau tidak pernah mengolah lahan pertanian pun menyatakan telah mengetahui industri dalam bidang pertanian karenaa responden pernah melakukan kunjungan ke industri pertanian, melakukan kegiatan pertanian sederhana, dan pernah mengikuti penyuluhan pertanian.

Berdasarkan hasil analisis dapat disimpulkan bahwa tingkat keterlibatan 
mahasiswa Program Studi Agribisnis Fakultas Pertanian Universitas Galuh Ciamis dalam karir bidang pertanian berada pada kategori tinggi (Gambar 6). dengan kisaran Rata-rata skor $14 \leq \mathrm{Q}<17$ yaitu 14 .

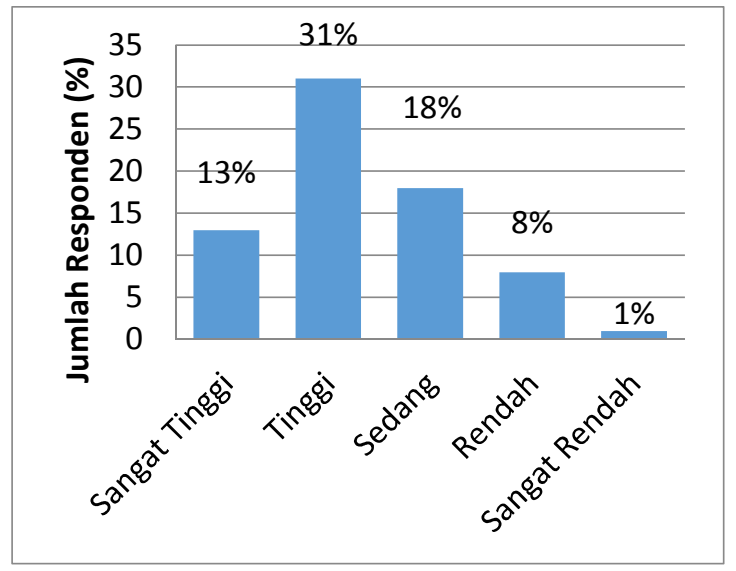

Gambar 6.

Keterlibatan Mahasiswa terhadap karir di Bidang pertanian

c. Perhatian

Tingginya ketertarikan responden terhadap karir di Bidang pertanian disebabkan responden setju, memilih berkuliah di Program studi agribisnis karena mempunyai perhatian untuk berkarir di Bidang pertanian dan menjadikan pertanian sebagai pekerjaan utama. Bahkan setelah lulus dan menjadi sarjana pertanian responden menyatakan setuju akan berjuang untuk mengembangkan pertanian secara intensif karena bidang pertanian menurut responden akan membuat karir responden lebih sukses.
Dari hasil analisis data menunjukkan bahwa tingkat perhatian Mahasiswa Program Studi Agribisnis Fakultas Pertanian Universitas Galuh Ciamis untuk berkarier di Bidang pertanian berada pada kategori tinggi (Gambar 7), dengan kisaran Rata-rata skor $16.8 \leq \mathrm{Q}<$ 20.4 yaitu 18 .

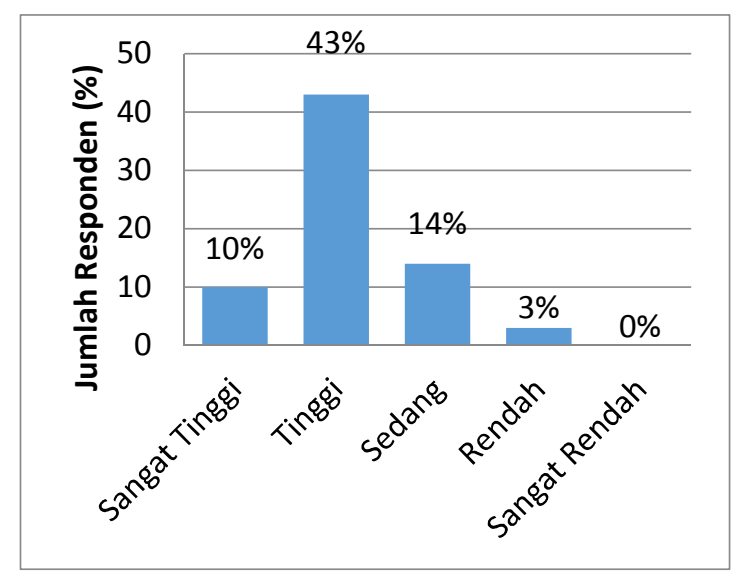

\section{Gambar 7.}

Ketertarikan Mahasiswa terhadap kariri di Bidang pertanian

d. Minat Mahasiswa

Dapat disimpulkan yang menyeabkan tingginya tingkat minat mahasiswa Program Studi Agribisnis Fakultas Pertanian Universitas Galuh Ciamis adalah, ketertarikan mahasiwa yang tinggi untuk berkarir di Bidang pertanian, mahasiswa sudah terlibat dalam kegiatan pertanian sehingga memunculkan minat untuk berkarir di Bidang pertanian, selain itu responden juga mempunyai perhatian yang lebih terhadap karir di Bidang pertanian. Hasil analisis 
tingkat minat mahasiswa Program Studi Agribisnis Fakultas Pertanian Universitas Galuh Ciamis untuk berkarir di Bidang pertanian berada pada kategori tinggi. dengan Rata-rata skor berada pada kisaran 47,6 $\leq \mathrm{Q}<$ 57,8 yaitu 50. (Gambar 9).

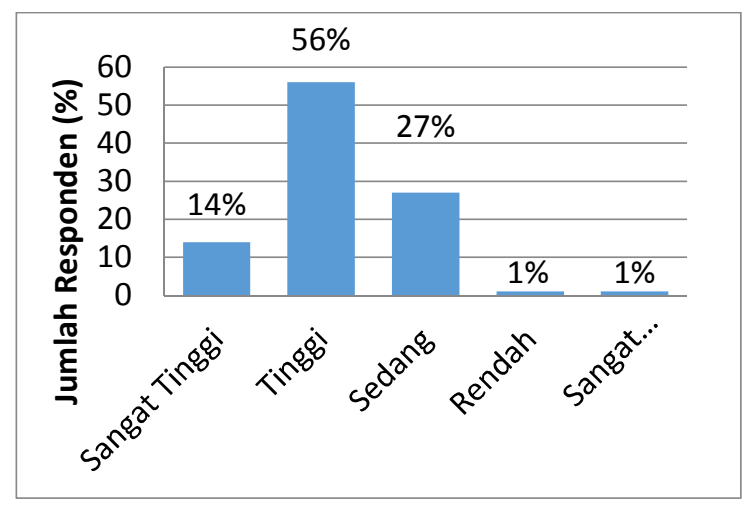

\section{Gambar 12.}

Minat Mahasiswa Terhadap kariri di Bidang Pertanian

\section{e. Hubungan Secara Parsial Persepsi dengan Minat}

Hasil penelitian menunjukkan nilai korelasi sebesar 0,674, menurut Sugiyono (2012) nilai tersebut termasuk dalam kategori hubungan yang cukup. Sedangkan hasil uji hipotesis mendapat nilai sebesar 0,00 yang lebih rendah dari $\alpha 0,05$ dan 0,01 Dari hasil pengujian hipotesis tersebut maka dapat diketahui bahwa terdapat hubungan positif yang nyata antara faktor internal persepsi dengan minat mahasiswa program studi agribisnis fakultas pertanian universitas galuh ciamis. Artinya bahwa faktor eksternal persepsi mahasiswa mempunyai hubungan yang positif dengan minat untuk berkarir di Bidang pertanian. Dengan hubungan positif tersebut menyatakan bahwa semakin tinggi faktor internal persepsi responden maka akan semakin tinggi pula minatnya untuk berkarir di Bidang pertanian.

Hasil penelitian menunjukkan nilai korelasi sebesar 0,523. Menurut Sugiyono (2012) menyatakan bahwa nilai tersebut termasuk dalam kategori hubungan yang cukup. Sedangkan uji hipotesis menunjukkan angka 0,00 yang lebih rendah dari $\alpha 0,05$ dan 0,01 . Hal tersebut menunjukkan bahwa terdapat hubungan positif yang nyata antara faktor eksternal persepsi dengan minat utnutk berkarir di Bidang pertanian. Berarti bahwa latar belakang keluarga responden, informasi yang diperoleh dan inovasi dibidang di pertanian berpengaruh terhadap minat untuk berkarir di Bidang pertanian. Maka dari itu semakin tinggi faktor internal persepsi responden akan semakin tinggi pula minatnya untuk berkarir di Bidang pertanian.

\section{KESIMPULAN DAN SARAN}

\section{Kesimpulan}

Persepsi mahasiswa Program Studi Agribisnis Fakultas Pertanian Universitas Galuh Ciamis berada pada kategori tinggi dengan Rata-rata nilai 31 dihitung dari 
tingkat faktor internal dan eksternal persepsi untuk berkarir di Bidang pertanian. Hasil pengukuran dari indikator persepsi dapat dijelaskan sebagai berikut, faktor internal persepsi mahasiswa berada pada kategori tinggi begitu pula dengan faktor eksternal persepsi mahasiswa yang berada pada kategori tinggi.

Minat mahasiswa Program Studi Agribisnis Fakultas Pertanian Universitas Galuh Ciamis termasuk pada kategori tinggi, dengan Rata-rata nilai sebesar 50. Sedangkan indikator minat yang terdiri atas ketertarikan, keterlibatan, dan perhatian berada pada kategori tinggi pula.

Secara parsial, hubungan Faktor persepsi dengan minat mahasiswa Program Studi Agribisnis Fakultas Pertanian Universitas Galuh Ciamis mempunyai hubungan positif yang nyata, hubungan positif tersebut menyatakan bahwa semakin tinggi faktor internal dan faktor eksternal persepsi responden maka akan semakin tinggi pula minatnya.

\section{Saran}

$$
\text { Mahasiswa pertanian sebagai }
$$
generasi muda yang terdididk dalam bidang pertanian harus bisa menjadi agen perubahan dengan ilmu yang dimilikinya serta memaksimalkan potensi yang dimiliki terutama dalam bidang pertanian.
Program Studi Agribisnis Fakultas Pertanian Universitas Galuh harus lebih memaksimalkan segala sumber daya yang ada untuk mempersiapkan mahasiswanya agar dapat bersaing di dunia karir atau pekerjaan setelah lulus dari perguruan tinggi.

\section{DAFTAR PUSTAKA}

Badan Pusat Statistik. 2013. Jumlah Rumah Tangga Petani Tahun 2012. Jakarta

Muwartami, D. 2014. Perepsi Mahasiswa Institut Pertanian Bogor Untuk Berkiprah Dibidang Kehutanan. [Skripsi]. Reposity IPB. Institut Pertanian Bogor.

Hutapea, H.D. (2016). The perception of acounting student about the factor wich of carieer selection(empiris study: accounting studen in medan north sumatra). Munich personal RePEc archive.medan.

Irianto, A. 2005. Born To Win Kunci Sukses Yang Takpernah Gagal. PT Gramedia Pustaka Utama. Jakarta.

Jusmin, E. 2012. Pengaruh Latar Belakang Keluarga, Kegiatan Praktik, Dan Pelaksaan Pembelajaran Kewirausahaan Terhadap Kesiapan Berwirausaha Siswa. [Jurnal Pendidikan Teknologi Dan Kejuruan Issn : 2477-2420]. Universitas Negeriyogyakarta.

Misbach, I.H. 2010. Dahsyatnya sidik jari. Visi Media. Bandung.

Muhson, A. 2012. Analisis Relevansi Perguruan Tinggi Dengan Dunia Kerja. [Jurnal Economia Volume 8. Nomor 1]. Universitas Negeri Yogyakarta.

Nazir, M. (2011). Metode penelitian. Ghalia Indonesia. Bogor. 
Pribadi, R. 2017. Memupuk Kesuburan Menebar Kemakmuran. PT Gramedia Pustaka Utama. Jakarta

Purwanto. 2010. Evaluasi Hasil Belajar. Pustaka Pelajar. Yogyakarta

Rahman, A. 2010. Strategi Dahsyat Marketing Mix For Small Busines: Cara Jitu Merontokan Pesaing. Trans Media. Jakarta

Ritonga, A. 2015. Analisis Peran Pemuda Terhadap Pembangnan Pertanian Lahan Pangan Berkelanjutan Di Kabupaten Labuhan Batu Utara. [jurnal Vol. 2, No. 3, ISSN Online 2356-4725]. Jurnal Pertanian Tropik. Sekolah Paskasarjana USU.

Romli, K. 2017. Komunikasi massa. Gramedia Widiasarana. Jakarta.

Santoso. 2012. Aplikasi SPSS Pada Statistika Non Parametrik. Elex Media Komputindo. Jakarta
Sjamsir, Z. 2017. Pembangunan pertanian dalam pusaran kearifan lokal. CV Sah Media. Makasar.

Sudjana. 2005. Metode Statistika. Tarsito. Bandung.

Sugiyono. 2016. Metode Penelitian Kuantitatif, Kualitatif, Dan R\&D. CV Alfabeta. Bandung.

. 2012. Metode Penelitian Kuantitatif, Kualitatif, Dan R\&D. CV Alfabeta. Bandung.

Werembinan, S.C. C, P.D.B. dan Lyndon, P.J.R.. 2018. Persepsi Generasi Muda Terhadap Kegiatan Pertanian Di Kelurahan Buha Kecamatan Mapanget Kota Manado. [jurnal Vol. 14, No. 3, ISSN 1907-4298]. Agr-sosio Ekonomi. Unsarat.

Yusuf, M. 2017. Penelitian Kuantitatif, Kualitatif \& Gabungan. Prenada Media. Jakarta. 